\title{
Violence in a community emergency room
}

J. WASSERBERGER, G. J. ORDOG, M. KOLODNY \& K. ALLEN Department of Emergency Medicine, Martin Luther King fr Hospital, Los Angeles, $\vec{\circ}$ California, USA

\section{SUMMARY}

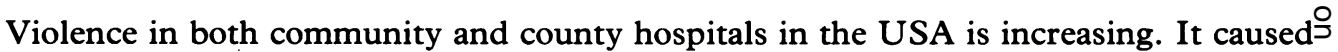
significant physical, emotional and economic hardship to many emergency department $\vec{\square}$ employees. We describe an incident that caused significant injury to an innocento bystander in a quiet upper-class community emergency department and outline $\stackrel{\$}{\Xi}$ procedures that hospitals and emergency department employees can take to combat this $\stackrel{\Phi}{-1}$ violence.

Policy, procedures, planning and methods must be available for appropriately trained 0 and equipped police officers to respond to such incidents.

The effects of such violent episodes on the emergency department staff are discusseđ. Methods to prevent such incidents are presented.

\section{INTRODUCTION}

The presence of an agitated, assaulting or violent patient in the emergency department is one of the most anxiety-provoking situations (Anon., 1978).

Lavoie \& Carter (1988) quantified the magnitude of the problem of violence in major inner city emergency departments in the USA as follows:

(1) $46 \%$ of the hospitals confiscated at least one weapon per month;

(2) $43 \%$ had at least one physical attack on a medical staff member per month;

(3) $7 \%$ describe acts of emergency department violence that resulted in death; and

(4) one hospital confiscated 300 weapons per month using a metal detector (Lavoie $\&$ Carter 1988).

At the King/Drew Medical Center in Los Angeles 4796 weapons were confiscated N from 456 patients over a 9 -year period. At least $25 \%$ of the major trauma patients that

Correspondence: Dr fonathan Wasserberger, Department of Emergency Medicine, Martin Luther King $\mathfrak{f r}_{\mathrm{D}}^{\stackrel{0}{\mathrm{C}}}$ General Hospital, 12021 South Wilmington Avenue, Los Angeles, California 90059, USA. 
presented to this Level I Trauma Center were carrying lethal weapons, of which five were automatic weapons and 12 sawn-off shotguns (Wasserberger et al., 1989).

We report a case that demonstrates such findings are not isolated to inner city hospitals but can and do occur in quiet upper middle-class communities. We outline an approach for the emergency department staff when faced with such an incident.

\section{CASE REPORT}

\section{Community hospital experience}

On a quiet night an experienced, board certified emergency physician in a quiet, middle-class emergency department attempted to examine a 28-year-old man who had presented with friends, but would not communicate with the admitting clerk.

The patient was cooperative, had a steady gait but appeared to be weak and was holding his head. The patient's vital signs were obtained without difficulty. Blood pressure was $164 / 70 \mathrm{~mm}$ of mercury and the pulse rate 84 beats per min and regular. The respiratory rate was 28 per min and the oral temperature $36 \cdot 5^{\circ} \mathrm{C}$.

Immediately after his arrival a 60 -year-old male in marked distress, pale, sweating and hypotensive arrived by paramedic ambulance. The new arrival was deaf and accompanied by his 78-year-old mother who translated for her son using sign language. His chief complaint was abdominal pain suggestive of a leaking abdominal aortic aneurysm. The emergency department physician called the surgeon and alerted the operating room crew. The nurse returned into the critical area where she suddenly noticed the 28-year-old male patient on top of the 78-year-old mother. She was flat on her back and the 28-year-old male was repeatedly stabbing the older woman in the abdomen with a 4-inch pocket knife. Four abdominal wounds had already been inflicted when the physician walked into the room. The young man was about to deliver another stab wound, this time to the heart. The physician blocked the knife's descent with an examination stool. Simultaneously the paramedic team who transported the patient with the aneurysm returned to the emergency department. They grasped two IV poles and swung them at the assailant.

As a result of the incident, the assailant sustained head, left chest and left upper quadrant abdominal trauma. In addition to the four abdominal stab wounds suffered, the old woman now had crushing substernal chest pain. An internal disaster was called, which should mobilize police and paramedic ambulance units, back-up on-cell emergency department and operating room personnel, a second surgeon and the anaesthetist. The Chief of Staff was notified.

The first surgical team arrived and immediately removed the old man from the emergency room and successfully resuscitated the patient with the aneurysm in the operating room. Team 2, consisting of an internist, surgeon and radiologist, immediately removed the old woman to the critical care unit, where she was found to have an acute myocardial infarction. CAT Scan failed to identify intra-abdominal bleeding. She did well with conservative management. The back-up emergency department crew arrived simultaneously with several police units. Four-way hand-cuffs were used to restrain the young man. Multiple intravenous infusions were commenced, appropriate 
bloods were drawn, a cross-table lateral c-spine X-ray was obtained following which the police escorted him to the Level I County Trauma Center 10 min away, as is protocol ${ }_{3}^{\circ}$ for an internal disaster occurring in a community hospital. He had in fact not sustained $\frac{\widehat{\Phi}}{\mathrm{\Phi}}$ any major injuries.

A drug screen was negative. He was subsequently diagnosed as schizophrenic and had $\stackrel{\vec{乛}}{\vec{\rho}}$ believed that the communication between the two older patients in sign language was? the communication of a man and a witch.

\section{DISCUSSION}

A violent episode can occur completely unexpectedly. We advocate the following measures.

(1) Have a training session to improve the recognition of danger.

(2) Rehearse a practical mechanism or response.

(3) Have a debriefing session after any major incident (Dibella, 1979)

\section{(1) Recognize the danger}

(a) Metal detection devices to screen for weapons may have to be considered in some $\stackrel{\mathbb{D}}{\mathscr{T}}$ circumstances (Anon, 1987; Lavoie \& Carter, 1988).

(b) All agitated patients should be seen immediately as they become more agitated they feel they are being ignored. 5,7,8,9 (Dibella, 1979; Rada, 1981; Atkinso 1982; Weissberg \& Dwyer 1987).

(c) Parking areas should be patrolled.

\section{(2) Initiate a practical plan}

(a) After dark have only one patrolled entrance and exit into the hospital.

(b) Have multiple methods for summoning the police including a buzzer at the clerk's desk and separate outside phone lines in the nurses' lounge and doctors' on-call room.

(c) Try not to be a hero. Weapon removal is for the police. A physician can ask the patient to place the weapon on the floor then both physician and patient leave that room without the physician trying to retrieve the weapon.

(d) When required to restrain a patient use the overwhelming force of at least five persons. These persons may need to use mattresses or other suitable devises to get between themselves and the assailant.

(e) Be sure that responding police units are suitably prepared for the situation they $\tilde{0}$ are called to by giving them adequate information.

(f) Avoid strait-jackets. They are claustrophobic, get hot and deny access to the patient's veins, chest, abdomen and heart. (Rada, 1981; Fauman et al., 1987).

(g) Sedation should be with haloperidol $5 \mathrm{mg}$ IM diazepan 10-20 mg IV every 
$30 \mathrm{~min}$ or chlorpromazine $100 \mathrm{mg}$ IM and the dose repeated if needed. An anaesthetist may elect in severely agitated and violent head trauma patients to use muscle relaxants and intubate and ventilate the patient. (Lion et al., 1969; Solomon, 1987; Crawford, et al., 1988; Eisenberg et al. 1988).

(h) Document all major incidents for medical legal purposes (Guirguis, 1978).

\section{(3) Debriefing the emergency room staff}

Have a debriefing session as soon as possible after the event and offer counselling where appropriate.

\section{REFERENCES}

Anon. (1978) Assaults on doctors. British Medical fournal 1, 1229.

Anon. (1987) Briefcase, Daily fournal (of Law) 17 June, 18.

Atkinson J. H. (1982) Managing the violent patient in the general hospital. Postgraduate Medicine 71, 193201.

Crawford T. O., Mitchell W. G. \& Fishman L. S. (1988) Very high dose phenobarbital for refractory status epilepticus in children. Neurology 38, 1035-40.

Dibella G. A. (1979) Educating staff to manage threatening paranoid patients. American fournal of Psychiatry 136, 333-5.

Eisenberg H. M., Frankowski R. F., Contant C. F., Marshall L. F. \& Walker M. D. (1988) High dose barbiturate control of elevated intercranial pressure on patients with severe head injuries. fournal of Neurosurgery 69, 15-23.

Engel F. (1986) Helping the employee victim of violence in hospitals. Hospital Community Psychiatry 37, 15964.

Fauman B., Terranova G. J. \& Tupin J. P. (1987) The violent patient. Patient Care August 15, 142-56.

Guirguis E. P. (1977) Management of disturbed patients, an alternative to the use of mechanical restraints. fournal of Clinical Psychology 39, 295-303.

Lavoie F. W. \& Carter G. L. (1988) Emergency department violence in United States teaching hospitals. (U/ AEMS Abst \#91 (1989) Annals of Emergency Medicine 17, 419.

Lion J. R., Bach-Y-Rita G. \& Erviv F. R. (1969) Violent patients in the emergency room. American fournal of Psychiatry 125, 120-5.

Ordog G. J., Wasserberger J. \& Balasubramaniam S. (1988) Shotgun wound ballistics. fournal of Trauma 28, 624-31.

Rada R. T. (1981) The violent patient: rapid assessment and mangement. Psychosomatics 22, 101-9.

Shevitz S. (1978) Emergency management of the agitated patient. Primary Care 5, 625-34.

Soloman G. (1987) Assaultive behaviour in Callaham. Current Concepts in Emergency Medicine B. C. Decker Inc., Philadelphia 333-6.

Wasserberger J., Ordog G. J. Kilodney M. et al. (1989) Weapons in a county emergency department. Submitted for publication. Fournal of Emergency Medicine (submitted for publication).

Weissberg M. P. \& Dwyer B. J. (1987) Safe strategies for recognizing and managing violent patients. Emergency Medicine Reports 8, 169-75. 